\title{
Total lactic acid bacteria, fiber content, and physical properties of Nata de pina between various parts of honey pineapple variety (Ananas comosus [L.] Merr. Var. Queen)
}

\author{
${ }^{1}$ Yovita, A., ${ }^{1,2, *}$ Afifah, D.N. and ${ }^{1,2}$ Candra, A. \\ ${ }^{I}$ Department of Nutrition Science, Faculty of Medicine, Universitas Diponegoro, Jl. Prof H. Soedarto, SH, \\ Tembalang, Semarang 50275, Indonesia \\ ${ }^{2}$ Center of Nutrition Research (CENURE), Universitas Diponegoro, Jl. Prof H. Soedarto, SH, Tembalang, \\ Semarang 50275, Indonesia
}

\author{
Article history: \\ Received: 29 December 2019 \\ Received in revised form: 14 \\ February 2020 \\ Accepted: 18 February 2020 \\ Available Online: 30 May \\ 2020
}

Keywords:

Nata de pina,

Honey pineapple variety,

Total lactic acid bacteria,

Fiber content,

Physical properties

DOI:

https://doi.org/10.26656/fr.2017.4(S3).S06

\begin{abstract}
Fiber is one of the nutrients that are important for health. Adequate fiber intake prevents several diseases such as stroke, colorectal cancer, heart disease, and diabetes mellitus. One of the foods that have high fiber content is Nata. This study is aimed to analyze the total lactic acid bacteria, fiber content, and physical properties of Nata de pina between various parts of honey pineapple variety. This study was a one-factor randomized experimental study with variations of Nata de pina from flesh, peel, and pineapple fruit core. Analysis of total lactic acid bacteria using Total Plate Count (TPC) methods and fiber content using enzymatic-gravimetric methods. The data described the physical properties by thickness using calipers, yield using scales, texture using texture analyzer, and color analysis using digital colorimetry. There were significant differences in the total lactic acid bacteria between the treatment group of Nata fermented water $12^{\text {th }}$ hour $(p<0.001), 2^{\text {nd }}$ day $(\mathrm{p}<0.001), 4^{\text {th }}$ day $(\mathrm{p}<0.001), 6^{\text {th }}$ day $(\mathrm{p}=0.007)$, and $8^{\text {th }}$ day $(\mathrm{p}=0.047)$. The highest total soluble and insoluble fiber of Nata de pina from the pineapple peel (1.92\% and $0.049 \%)$. There were differences in physical properties test that include thickness, yield $(p<0.001)$, and texture. There were differences in a color analysis that include $L^{*}(p=0.005), a^{*}$ $(\mathrm{p}=0.012)$, and $\mathrm{b}^{*}(\mathrm{p}=0.002)$. Various parts of honey pineapple affect total lactic acid bacteria, fiber content, thickness, yield, texture, and color of Nata de pina.
\end{abstract}

\section{Introduction}

Fiber is one component of nutrition that is beneficial to health. Dietary fiber is a part of plants that cannot be digested by the digestive tract. But it can prevent several diseases such as stroke, heart disease, and diabetes mellitus (Li and Komarek, 2017; Hapsari et al., 2018). Dietary fiber can be divided into soluble dietary fiber (SDF) and insoluble dietary fiber (IDF). Generally, soluble dietary fibers include pectin, gum, and glucans. Whereas included in insoluble fiber are cellulose, hemicellulose, and lignin. About one-third of the Total Dietary Fiber (TDF) is soluble dietary fiber, while the largest group is insoluble fiber. (Dai et al., 2017; Yang et al., 2017).

Consumption of enough fiber based on the recommended amount can reduce the risk of stroke, colorectal cancer, cardiovascular disease, and type 2 diabetes (Li et al., 2017). A diet high in grains, fruits, and vegetables can prevent cancer because of the high fiber content. Fiber provides a protective effect from cancer cells by increasing the fecal period and frequency of bowel movements, thereby reducing contact between carcinogens and colonic lumen. In the intestinal lumen, the fiber will ferment and produce fatty acids which will stimulate the growth of the colonic mucosa and induce apoptosis (Hapsari et al., 2018).

One of the fruits that become Indonesia's main commodity is pineapple. Based on Fixed figures states that in 2014 the pineapple production reached 1.84 million tons. (Pusat Data dan Sistem Informasi Pertanian Kementrian Pertanian., 2015). Pineapple which has the Latin name Ananas Comosus L. Merr is one type of fruit that is much in demand by the public. Honey pineapple is the most popular grown in Indonesia. The nutritional content found in pineapple is calcium, potassium, vitamin $\mathrm{C}$, carbohydrates, fiber, water, and various other minerals (Hossain et al., 2015). Pineapple can be 
consumed directly or in the form of preparations. One of the processed foods made from pineapple is Nata (Department of Health and Ageing Office of the Gene Technology Regulatory, 2008).

Nata is a fermented product by the Acetobacter xylinum which is grown on media containing carbohydrates, vitamins, and inorganic acids that are needed (Almeida et al., 2013). Nata is a low-calorie food product with $2.5 \%$ fiber content and $98 \%$ water (Nugroho et al., 2015; Rizal et al., 2016). The fiber contained in Nata is classified as insoluble fiber that cannot reduce cholesterol levels in the blood but can prevent the occurrence of colon cancer, difficulty removing large water, obesity, and diabetes mellitus (Mirmiran et al., 2016). The fiber and water content affects the texture of Nata. The higher the fiber content in Nata, the lower the level of elasticity (Ratnaningsih et al., 2017). Nata made from pineapple is called Nata de pina. Nata de pina is not only made from the flesh of the fruit. Pineapple waste such as peel and fruit core also has the potential to be made into Nata de pina (Rizal et al., 2016) The results of the study indicated that pineapple made from pineapple peel has the largest thickness of $1.11 \mathrm{~cm}$ while pineapple made from pineapple flesh and pineapple fruit core respectively - each has a thickness of $0.2 \mathrm{~cm}$ and $0.74 \mathrm{~cm}$ (Hamad et al., 2017).

In the fermentation process in making Nata, it is known that there is an activity of lactic acid bacteria (Nugroho et al., 2015). Bacteria are the most common microorganisms found in foods that are fermented naturally or using a starter. Lactic acid bacteria are one of the bacteria found in fermented foods or drinks that are acidic (Tamang et al., 2015). In general, lactic acid bacteria are a group of gram-positive bacteria that can convert glucose, fructose, and other sugars into lactic acid. This bacterium is beneficial for health, especially in the human digestive system. Research conducted by Jiachao Zhang et al. (2017) regarding the microorganisms in Nata de coco during fermentation, it was stated that there were the Lactobacillus bacteria which is one of the genera of lactic acid bacteria. The results of this study also state that the content of acetic acid and lactic acid increases during fermentation (Anna et al., 2010). Lactic acid bacteria produce exopolysaccharides which affect the texture and viscosity of fermented products (Zamfir et al., 2014; Gupta et al., 2018). Therefore, this work is aimed to identify total lactic acid bacteria, fiber content, and physical properties of Nata de pina between various parts of honey pineapple variety.

\section{Materials and methods}

\subsection{Materials}

Honey pineapple was collected from Pemalang, Indonesia. Coconut water was obtained at Semarang, Indonesia. While coconut water, sugar, vinegar, etc were purchased from local market.

\subsection{Preparation making Nata de coco}

Coconut water used for making Nata de coco as control. Coconut water was heated at $100^{\circ} \mathrm{C}$ in a water bath for 10-15 mins. During the process, $7.5 \%$ sucrose and $0.5 \%$ urea were added into the media. Glacial acetic acid was added to adjust the $\mathrm{pH}$ to 4 . After heating, each media was put into the trays that had previously been sterilized. Each tray was closed using newspaper and glued with rubber to minimize contamination. The tray then placed at room temperature $\left(28-31^{\circ} \mathrm{C}\right)$ for $12 \mathrm{hrs}$ and $10 \%$ of A. xylinum starter was added in media. After the starter was added, the tray was closed again and fermented for 8 days.

\subsection{Preparation of pineapple juices and making of Nata de pina}

The peel, flesh, and pineapple fruit core used for fermentation media. Each part of pineapple fruit was mixed with water in the ratio of 1:2. The juices were heated at $100^{\circ} \mathrm{C}$ in a water bath for $10-15$ mins. During the process, $7.5 \%$ sucrose and $0.5 \%$ urea were added into the media. Glacial acetic acid was added to adjust the $\mathrm{pH}$ to 4. After heating, each media was put into the trays that had previously been sterilized. Each tray was closed using newspaper and glued with rubber to minimize contamination. The tray then placed at room temperature $\left(28-31^{\circ} \mathrm{C}\right.$ ) for $12 \mathrm{hrs}$ and $10 \%$ of A. xylinum starter was added in media. After the starter was added, the tray were closed again and fermented for 8 days. (Sutanto, 2012)

\subsection{Determination of total lactic acid bacteria}

Analysis of total lactic acid bacteria on fermented media for $12^{\text {th }}$ hour, $2^{\text {nd }}$ day, $4^{\text {th }}$ day, $6^{\text {th }}$ day, and $8^{\text {th }}$ day. Nata fermented water was use for the analysis of total lactic acid via Total Plate Count (TPC).

\subsection{Determination of fiber content}

The test used for fiber contents determination were enzymatic-gravimetric methods. (Prosky et al., 1985; Prosky et al., 1994) Fiber contents analysis were carried out at the laboratory of Saraswanti Indo Genetech.

\subsection{Determination of physical properties}

The physical properties were evaluated by thickness, 
yield, texture, and color measurement. The thickness determination of Nata samples was used calipers in millimeter. Determination of yield used scales in the ratio between the weight of Nata produced and the weight of media during the Nata making process. The texture determination which is the hardness of Nata samples were used texture analyzer in $\mathrm{kg} / \mathrm{m}^{2}$. The color of Nata samples was determined using digital colorimetry according to the $L^{*} a^{*} b^{*}$ value with two repetitions. $L^{*}$ (lightness/darkness that ranges from 0 to 100 ), $a^{*}$ (yellowness/greenness that ranges from -120 to $120)$ and $b^{*}$ (yellowness/blueness that range from -120 to 120) were measured (Salehi and Kashaninejed et al., 2014).

\subsection{Statistical analysis}

Data analysis was performed using SPSS v.16.0 that had previously been tested for normality using the Shapiro-Wilk test. The total lactic acid bacteria were analyzed using the One way ANOVA test if the data were normally distributed and the Kruskal-Wallis test if the data were abnormally distributed followed by the Tukey test to find out the real difference between treatments. Physical properties were analyzed using the Kruskal-Wallis test and continued with the Mann Whitney test to find out the real difference.

\section{Results and discussion}

\subsection{Total lactic acid bacteria}

Based on Table 1, there were significant differences in total lactic acid bacteria between the treatment group of Nata fermented water $12^{\text {th }}$ hour $(p<0.001), 2^{\text {nd }}$ day $(\mathrm{p}<0.001), 4^{\text {th }}$ day $(\mathrm{p}<0.001), 6^{\text {th }}$ day $(\mathrm{p}=0.007)$, and $8^{\text {th }}$ day $(\mathrm{p}=0.047)$. Figure 1 shows Nata de pina from pineapple peel is the highest total lactic acid bacteria while Nata de pina from fruit core is the lowest total lactic acid bacteria. The acidic conditions in the fermentation process caused fermented water contains lactic acid bacteria (Zhang et al., 2017). Lactic acid bacteria are gram-positive bacteria that can grow on low pH sugar-containing media (Anna et al., 2010). The highest total LAB is required in Nata fermented water made from coconut water. The presence of natural LAB and more energy sources such as calcium, fructose, and sucrose in coconut water increases bacterial growth (Tan et al., 2014). Fermentation of pineapple can increase the growth of lactic acid bacteria. Besides, lactic acid bacteria are also contained in pineapple. Pineapple fermented water on the fruit peel contains more lactic acid bacteria compared to pineapple fermented water made from flesh and fruit core. The difference in lactic acid bacteria is caused by the fermentation of pineapple waste containing more lactic acid bacteria (Di Cagno et al., 2010; Niederreiter et al., 2018). Increasing the total lactic acid bacteria during the fermentation process produces acid so that can inhibit the growth of bacteria. Based on statistics, the total lactic acid bacteria in Nata fermented water does not improve the texture of the Nata produced because Nata was not the end product of lactic acid bacteria fermentation. The texture of Nata was affected by the water and cellulose content. (Ratnaningsih et al., 2017)

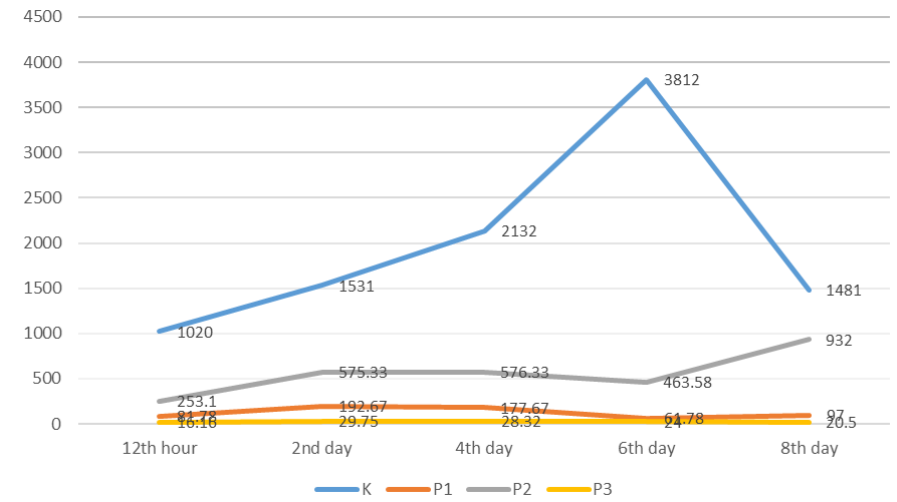

Figure 1. Total lactic bacteria

\subsection{Fiber content}

The result in Table 2 shows that Nata de pina from pineapple fruit had the highest soluble fiber $(1.92 \%)$ and insoluble fiber $(0.049 \%)$. The pineapple fruit peel has the potential to be used for Nata. The study showed that the pineapple fruit peel contains higher carbohydrates than other pineapple parts. A. xylinum is a bacterium from the family of acetic acid bacteria can convert carbohydrates into acids acetate (Hamad et al., 2017). In this study, Nata de coco had a higher soluble fiber compared to Nata de pina. Coconut water contains more sugar and

Table 1. Total lactic bacteria

\begin{tabular}{cccccc}
\hline \multirow{2}{*}{ Sample } & $12^{\text {th }}$ hour & $2^{\text {nd }}$ day & $4^{\text {th }}$ day & $6^{\text {th }}$ day & $8^{\text {th }}$ day \\
\cline { 2 - 6 } & $\left(10^{12} \mathrm{CFU} / \mathrm{mL}\right)$ & $\left(10^{12} \mathrm{CFU} / \mathrm{mL}\right)$ & $\left(10^{12} \mathrm{CFU} / \mathrm{mL}\right)$ & $\left(10^{12} \mathrm{CFU} / \mathrm{mL}\right)$ & $\left(10^{12} \mathrm{CFU} / \mathrm{mL}\right)$ \\
\hline K & $1020 \pm 187.38^{\mathrm{b}}$ & $1531 \pm 368.95^{\mathrm{c}}$ & $2132 \pm 324.36^{\mathrm{c}}$ & $3812 \pm 2.15^{\mathrm{b}}$ & $1481 \pm 1.1$ \\
P1 & $81.78 \pm 24.44^{\mathrm{a}}$ & $192.67 \pm 91.21^{\mathrm{ab}}$ & $177.67 \pm 99.97^{\mathrm{ab}}$ & $61.78 \pm 54.47^{\mathrm{a}}$ & $97 \pm 57.98$ \\
P2 & $253.1 \pm 134.68^{\mathrm{a}}$ & $575.33 \pm 90.27^{\mathrm{b}}$ & $576.33 \pm 101.75^{\mathrm{b}}$ & $463.58 \pm 303.19^{\mathrm{a}}$ & $932 \pm 620.21$ \\
P3 & $16.16 \pm 2.35^{\mathrm{a}}$ & $29.75 \pm 3.08^{\mathrm{a}}$ & $28.32 \pm 4.77^{\mathrm{a}}$ & $24 \pm 0.03^{\mathrm{a}}$ & $20.5 \pm 0.58$ \\
p $^{*}$ & 0 & 0 & 0 & 0.007 & 0.047 \\
\hline
\end{tabular}

*Using One way anova Test. Equal letters (same column) indicate that there is significant difference among the values ( $\mathrm{p}<0.05$ ). $\mathrm{K}=$ control/Nata de coco; $\mathrm{P} 1=$ Nata from fruit flesh; $\mathrm{P} 2=$ Nata from fruit peel; $\mathrm{P} 3=$ Nata from fruit core 
nitrogen for the growth of the A. xylinum. A. xylinum is a cellulose-producing bacteria. This bacterium works to convert glucose into gluconic acid and stimulate organic acids. A xylinum can grow and work on media that contain enough nutrients such as carbon, nitrogen and other minerals. In this study, pineapple peel which is a waste can be potentially made into Nata de pina as it is the most nutritious part of the pineapple (Lestari, 2014; Hamad et al., 2017).

Table 2. Fiber content

\begin{tabular}{ccc}
\hline Sample & Soluble fibre (\%) & Insoluble fibre (\%) \\
\hline K & $2.22 \pm 0.014$ & $0.0098 \pm 0.0007$ \\
P1 & $0.305 \pm 0.007$ & $0.0195 \pm 0.0007$ \\
P2 & $1.92 \pm 0.014$ & $0.049 \pm 0.0014$ \\
P3 & $0.195 \pm 0.007$ & $0.0055 \pm 0.0002$ \\
\hline
\end{tabular}

$\mathrm{K}=$ control/Nata de coco; P1 = Nata from fruit flesh; $\mathrm{P} 2=$ Nata from fruit peel; $\mathrm{P} 3=$ Nata from fruit core

\subsection{Physical properties}

\subsubsection{Thickness}

According to the study, Nata de coco showed the highest thickness $(0.97 \mathrm{~cm})$. The thickness Nata de pina showed that Nata from pineapple fruit peel had the highest thickness $(0.39 \mathrm{~cm})$ compared to Nata de pina from flesh $(0.27 \mathrm{~cm})$ and core $(0.15 \mathrm{~cm})$. Nata thickness is one of the parameters of making Nata (Sahin et al., 2006) The results of the study showed that Nata de coco has a higher thickness than Nata de pina. Coconut water contains more nutrients than pineapple such as glucose, fructose, and sucrose (Tan et al., 2014; Hamad et al., 2017). The main sugar content in coconut water is fructose. Coconut water contains $32.5 \mathrm{mg} / \mathrm{mL}$ of fructose, while the fructose content of pineapple is 10 $\mathrm{mg} / \mathrm{mL}$ (Hong et al., 2013; Manivannan et al., 2018). Fructose is the main carbon source for bacterial growth to produce cellulose (Zeng et al., 2011). Nata de pina produced a lower thickness than Nata de coco. Pineapple contains polysaccharide that causes pineapple juices to become turbid. Turbid media increases the level of viscosity so that oxygen supply is obstructed (Ernawati, 2012)

Nata from pineapple peel produces a higher thickness than other fruit parts. The highest fructose content is found in the pineapple peel (Nadzirah et al., 2013). Nata from pineapple core produces the lowest thickness due to the oxalate content in pineapple. It is known that the highest oxalate content is found in pineapple core. Oxalate is an organic acid that can inhibit the formation of cellulose (Siener et al., 2015; Lu et al., 2016). In the Nata making process, sugar as a carbon source is important. The availability of sugar in the media will affect bacterial growth. A. xylinum needs sugar as a source of carbon for cell metabolism. Media that contains more sugar will produce higher Nata
(Lestari et al., 2014; Hamad et al., 2017).

\subsubsection{Yield}

The result of yield anaylsis showed that there were significant differences between the mean scores for the sample $(\mathrm{p}<0.05)$. Also, it is obvious from the results that Nata de pina from pineapple fruit peel $(12.02 \%)$ had the highest yield compare to Nata de pina from flesh $(8.86 \%)$ and core $(5.53 \%)$ of pineapple fruit. This study also showed that Nata de coco produced higher yield compared to Nata de pina. Coconut water contains more glucose, fructose, and sucrose than pineapple (Tan et al., 2014; Hamad et al., 2017). The yield is the ratio between the weight of Nata produced and the weight of media during the Nata making process. Nata yield calculation is performed to determine the percentage of Nata biomass obtained from the fermentation process by the A. xylinum (Sahin et al., 2006). The yield of Nata de pina from pineapple fruit peel is higher than other parts of the fruit. The yield of Nata can be affected by the thickness of the Nata so that the thicker the Nata formed, the higher the yield (Talenta, 2018). This study showed that the highest Nata thickness is found in Nata de coco and the lowest in Nata which made from pineapple fruit core. The yield value is directly proportional to the thickness of the Nata produced.

\subsubsection{Texture}

The results of texture analysis are shown in Table 3. The lowest texture was obtained on Nata de pina from pineapple peel $\left(38.5 \mathrm{~kg} / \mathrm{m}^{2}\right)$ followed by Nata de pina from pineapple core $\left(57.75 \mathrm{~kg} / \mathrm{m}^{2}\right)$ and pineapple flesh $\left(81.25 \mathrm{~kg} / \mathrm{m}^{2}\right)$. The texture is an important component in food that is related to product acceptance by consumers. Texture can be affected by cellulose formed during the fermentation process. Cellulose is the main product of Nata, which is classified as insoluble fiber. High levels of insoluble fibre affect the high content of insoluble fiber which then will affect the texture of Nata to be lower (Sahin et al., 2006; Ratnaningsih et al., 2017).

\subsubsection{Color}

The result showed that there are significant differences between the lightness $(p=0.005)$, redness $(\mathrm{p}=0.012)$, and yellowness $(\mathrm{p}=0.002)$ value. The lowest $L$ (lightness) value of Nata de pina is produced from pineapple peel and the highest value from pineapple flesh. Since the major color of pineapple flesh is yellow, while the major color of pineapple peel is greenish. The value of $L$ (lightness) is the level of brightness that ranges from zero to one hundred on the chromameter. $L$ value of close to 100 shows that the analyzed sample has a high brightness (Nugrahani., 2014). The lowest $a$ (redness) value of Nata de pina is produced from flesh 
Table 3. Physical properties

\begin{tabular}{|c|c|c|c|c|c|c|}
\hline Sample & Thickness $(\mathrm{cm})$ & $\frac{\text { Yield }}{(\%)}$ & $\frac{\text { Texture }}{\left(\mathrm{kg} / \mathrm{mm}^{2}\right)}$ & $L^{*}$ & $a^{*}$ & $b^{*}$ \\
\hline $\mathrm{K}$ & $0.97 \pm 0.014$ & $60.1 \pm 1.15^{\mathrm{b}}$ & $87 \pm 2.4$ & $64(64-65)^{\mathrm{a}}$ & $-18(-19-(-17))^{\mathrm{ab}}$ & $37(36-37)^{d}$ \\
\hline $\mathrm{P} 1$ & $0.27 \pm 0.007$ & $8.86 \pm 0.53^{\mathrm{a}}$ & $81.25 \pm 1.1$ & $69(67-69)^{b}$ & $-19(-20-(-19))^{\mathrm{a}}$ & $21(21-22)^{b}$ \\
\hline $\mathrm{P} 2$ & $0.39 \pm 0.014$ & $12.02 \pm 1.22^{\mathrm{a}}$ & $38.5 \pm 5.65$ & $63.5(62-64)^{\mathrm{a}}$ & $-17(-17-(-16))^{\mathrm{b}}$ & $26(25-26)^{c}$ \\
\hline P3 & $0.15 \pm 0.007$ & $5.53 \pm 0.3^{\mathrm{a}}$ & $57.75 \pm 1.87$ & $68(67-69)^{\mathrm{b}}$ & $-19(-20-(-17))^{\mathrm{a}}$ & $18.5(17-20)^{\mathrm{a}}$ \\
\hline $\mathrm{p}$ & & $0.000^{\mathrm{xz}}$ & & $0.005^{\mathrm{yz}}$ & $0.012^{\mathrm{yz}}$ & $0.002^{\mathrm{yz}}$ \\
\hline
\end{tabular}

${ }^{\mathrm{x}}$ Using One way anova Test; ${ }^{\mathrm{y}}$ Kruskal-Wallis; ${ }^{\mathrm{z}}$ Post-hoc Mann Whitney Test. Equal letters (same column) indicate that there is significant difference among the values $(\mathrm{p}<0.05) . \mathrm{K}=$ control/Nata de coco; $\mathrm{P} 1=$ Nata from fruit flesh; P2 = Nata from fruit peel; P3 = Nata from fruit core

and pineapple core while the highest value from pineapple peel. The value of $a$ (redness) obtained in this study is negative, which indicates that the Nata has a greenish color. This study also showed that the lowest $b$ (yellowness) value from pineapple core and the highest $b$ from Nata de coco. The value of $b$ (yellowness) obtained in this study is positive, which shows that the Nata had a yellowish color. Yellowish color that forms on Nata de pina because of the basic color of pineapple. While the yellowish color of Nata de coco affected by the sugar that heated in the process of heating the media (Rizal et al., 2013; Nugrahani, 2014).

\section{Conclusion}

Various parts of honey pineapple affect the total lactic acid bacteria, fiber content, thickness, yield, texture, and color of Nata de pina. Besides, lactic acid bacteria do not show some effect in terms of texture. The physical properties analysis such as thickness, yield and color have differences. Nata de pina from pineapple fruit peel contained the highest soluble and insoluble fiber that means it can be alternate food for adequate fiber intake and prevents several noncommunicable disease.

\section{Conflict of Interest}

The authors declare no conflict of interest.

\section{Acknowledgments}

The author would like to thank the Ministry of Research, Technology and Higher Education of the Republic of Indonesia for financial support throughout this research.

\section{References}

Almeida, D.M., Prestes, R.A., da Fonseca, A.F., Woiciechowski, A.L. and Wosiacki, G. (2013). Minerals consumption by Acetobacter xylinum on cultivation medium on coconut water. Brazilian Journal of Microbiology, 1(44), 197-206. https://

\section{doi.org/10.1590/S1517-83822013005000012}

Dai, F.J. and Chau, C.F. (2017). Classification and regulatory perspectives of dietary fiber. Journal of Food and Drug Analysis, 25(1), 37-42. https:// doi.org/10.1016/j.jfda.2016.09.006

Australian Government. (2008). Department of Health and Ageing Office of the Gene Technology Regulatory. Biology of Ananas comosus var. comosus (Pineapple). Retrieved from Australian Government: http://www.ogtr.gov.au/internet/ogtr/ publishing.nsf/Content/pineapple-3/\$FILE/ biologypineapple08_2.pdf

Di Cagno, R., Cardinali, G., Minervini, G., Antonielli, L., Rizzello, C.G., Ricciuti, P. and Gobbetti, M. (2010). Taxonomic structure of the yeasts and lactic acid bacteria microbiota of pineapple (Ananas comosus L. Merr.) and use of autochthonous starters for minimally processing. Food Microbiology, 27(3), 381-389. https://doi.org/10.1016/j.fm.2009.11.012

Ernawati, E. (2012). Pengaruh Sumber Nitrogen terhadap Karakteristik Nata de Milko. Surakarta, Indonesia: Universitas Sebelas Maret. [In Bahasa Indonesia].

Gupta, R., Jeevaratnam, K. and Fatima, A. (2018). Lactic Acid Bacteria: Probiotic Characteristic, Selection Criteria, and its Role in Human Health (A Review ). Journal of Emerging Technologies and Innovative Research, 5(10), 411-424.

Hamad, A., Hidayah, B.I., Solekhah, A. and Septhea, A.G. (2017). Potensi kulit nanas sebagai substrat dalam pembuatan Nata de pina. Jurnal Riset Sains dan Teknologi, 1, 9-14. [In Bahasa Indonesia].

Hapsari, P.K. and Murbawani, E.A. (2018). Hubungan Asupan Serat, Lemak dan Kalsium dengan Kejadian Karsinoma Kolorektal di Semarang. Journal of Nutrition College, 7(4), 461-468.

Hong, K., Xu, H., Wang, J., Zhang, L., Hu, H., Jia, Z., Gu, H., Quanguang, H. and Gong, D. (2013). Quality changes and internal browning developments of summer pineapple fruit during storage at different temperature. Scientia Horticulturae, 151, 68-74. 
https://doi.org/10.1016/j.scienta.2012.12.016

Hossain, F., Akhtar, S. and Anwar, M. (2015). Nutritional Value and Medicinal Benefits of Pineapple. International Journal of Nutrition and Food Science, 4(1), 84-88. https://doi.org/10.11648/ j.ijnfs.20150401.22

Lestari, P., Elfrida, N., Suryani, A. and Suryadi, Y. (2014). Study on the Production of Bacterial Cellulose from Acetobacter xylinum using AgroWaste. Journal of Biological Sciences, 7(1), 75-80. https://doi.org/10.12816/0008218

Li, Y.O. and Komarek, A.R. (2017). Dietary fibre basics: Health, nutrition, analysis, and applications. Food Quality and Safety, 1(1), 47-59.

Lu, H., Jia, Q., Chen, L. and Zhang, L. (2016). Effect of Organic Acids on Bacterial Cellulose Produced by Acetobacter xylinum. Journal of Microbiology and Biotechnology, 5(2), 3-8.

Manivannan, A., Bhardwaj, R., Padmanabhan, S., Suneja, P., Hebbar, K.B. and Kanade, S.R. (2018). Biochemical and nutritional characterization of coconut (Cocos nucifera L.) haustorium. Food Chemistry, 238, 153-159. https://doi.org/10.1016/ j.foodchem.2016.10.127

Mirmiran, P., Bahadoran, Z., Moghdam, S.K., Vakili, A.Z. and Azizi, F. (2016). A Prospective Study of Different Types of Dietary Fiber and Risk of Cardiovascular Disease: Tehran Lipid and Glucose Study. Nutrients, 8(11), 686. https://doi.org/10.1016/ j.foodchem.2016.10.127

Nadzirah, K.Z., Zainal, S., Noriham, A., Normah, I., Roha, A.M.S. and Nadya, H. (2013). Physicochemical properties of pineapple variety N36 harvested and stored at different maturity stages. International Food Research Journal, 20(1), 225231.

Niederreiter, L., Adolph, T.E. and Tilg, H. (2018). Food, microbiome and Colorectal Cancer. Current Colorectal Cancer Reports. Department of Internal Medicine I, Gastroenterology, Hepatology and Endocrinology, Medical University Innsbruck, Austria, 14(6), 217-225. https://doi.org/10.1016/ j.dld.2018.03.030

Nugrahani, A. (2014). Physical Properties and Sensory Preference of Bakpia Skin Substituted with Cassava Flour. Surakarta, Indonesia: Universitas Muhammadiyah Surakarta.

Nugroho, D.A. and Aji, P. (2015). Characterization of Nata de Coco Produced by Fermentation of Immobilized Acetobacter xylinum. Italian Oral Surgeryl, 3, 278-282. https://doi.org/10.1016/ j.aaspro.2015.01.053
Prosky, L., Asp, N.G., Furda, I., Devries, J.W., Schweizer, T.F. and Harland, B.F. (1985). Determination of total dietary fiber in foods and food products: Collaborative study. Journal of $A O A C$ International, 68(4), 677-679. https:// doi.org/10.1093/jaoac/68.4.677

Prosky, L., Schweizer, T.F., Devries, J.W., Furda, I. and Lee, S.C. (1994). Determination of soluble dietary fiber in foods and food product: Collaborative study. Journal of AOAC International, 77(3), 690-694. https://doi.org/10.1093/jaoac/77.3.690

Pusat Data dan Sistem Informasi Pertanian (2015) Outlook: Komoditas Pertanian Subsektor Hortikultura Nenas. Kementrian Pertanian. [In Bahasa Indonesia].

Ratnaningsih, Ginting, E., Adie, M.M. and Harnowo, D. (2017). Sifat fisikokimia dan kandungan serat pangan galur-galur harapan kedelai. Jurnal Penelitian Pascapanen Pertanian, 14, 35-45. https:// doi.org/10.21082/jpasca.v14n1.2017.35-45

Rizal, H.M., Pandiangan, D.M. and Saleh, A. (2013). Pengaruh penambahan gula, asam asetat dan waktu fermentasi terhadap kualitas Nata de corn. Jurnal Teknik Kimia, 19(1), 34-39.

Rizal, M. and Triwidyawati, A. (2016). Product Processed Diversified of Pineapple for Food Security Support in East Kalimantan. Prosiding Seminar Nasional Masyarakat Biodiversitas Indonesia, 1(8), 2011-2015.

Sahin, S. and Sumnu, S.G. (2006). Size, Shape, Volume, and Related Physical Attributes. In Heldman, D.R. (ed.) Physical Properties of Foods, p. 90. Ankara: Springer Science and Business Media.

Salehi, F. and Kashaninejad, M. (2014). Effect of Different Drying Methods on Rheological and Textural Properties of Balangu Seed Gum. Drying Technology, 32(6), 720-727. https:// doi.org/10.1080/07373937.2013.858264

Siener, R., Seidler, A., Voss, S. and Hesse, A. (2015). The oxalate content of fruit and vegetable juices, nectars and drinks. Journal of Food Composition and Analysis, 45, 108-112. https://doi.org/10.1016/ j.jfca.2015.10.004

Sutanto, A. (2012). Pineapple Liquid Waste As Nata De Pina Raw Material. Makara Seri Teknologi, 16(1), 63-67. https://doi.org/10.1016/j.jfca.2015.10.004

Talenta, T. (2018.) Effect of Various Types of Sugar on Thickness, Rendemen, and Organoleptic Test of Nata de Durio. Yogyakarta: Universitas SaNata Dharma.

Tamang, J.P., Thapa, N., Tamang, B., Rai, A. and Chettri, R. (2015). In Tamang, J.P. (Ed.) 
Microorganisms in Fermented Foods and Beverages. $1^{\text {st }}$ ed. London Taylor and Francis Group. https:// doi.org/10.1201/b18279

Tan, T., Cheng, L., Bhat, R., Rusul, G. and Easa, A.M. (2014). Composition, physicochemical properties and thermal inactivation kinetics of polyphenol oxidase and peroxidase from coconut (Cocos nucifera) water obtained from immature, mature and overly-mature coconut. Food Chemistry, 142, 121128. https://doi.org/10.1016/j.foodchem.2013.07.040

Yang, Y., Ma, S., Wang, X. and Zheng, X. (2017). Review: Modification and Application of Dietary Fiber in Foods. Journal of Chemistry, 2017, 1-8. https://doi.org/10.1155/2017/9340427

Zamfir, M., Cornea, C., De Vuyst, L. and. Grosu-Tudor, S. (2014). Biodiversity and Biotechnological Potential of Lactic Acid Bacteria. AgroLife Scientific Journal, 3(1), 169-176.

Zeng, X., Small, D.P. and Wan, W. (2011). Statistical optimization of culture conditions for bacterial cellulose production by Acetobacter xylinum BPR 2001 from maple syrup. Carbohydrate Polymers, 85 (3), 506-513. https://doi.org/10.1016/ j.carbpol.2011.02.034

Zhang, J., Yang, Y., Deng, J., Wang, Y., Hu, Q., Li, C. and Liu, S. (2017). Dynamic profile of the microbiota during coconut water pre-fermentation for Nata de coco production. LWT - Food Science and Technology, 81, 87-93. https://doi.org/10.1016/ j.lwt.2017.03.036 